\title{
Ice volume estimation inferred from ice thickness and surface measurements for Continental Glacier, Wind River Range, Wyoming, USA
}

\author{
Jeffrey A. VANLOOY, ${ }^{1}$ Clément MIÈGE, ${ }^{2}$ Gregory S. VANDEBERG, ${ }^{3}$ \\ Richard R. FORSTER ${ }^{2}$ \\ ${ }^{1}$ Department of Earth System Science and Policy, University of North Dakota, Grand Forks, ND, USA \\ E-mail: jvanlooy@aero.und.edu \\ ${ }^{2}$ Department of Geography, University of Utah, Salt Lake City, UT, USA \\ ${ }^{3}$ Department of Geography, University of North Dakota, Grand Forks, ND, USA
}

\begin{abstract}
The Wind River Range in Wyoming, USA, contains the largest concentration of glacial mass in the Rocky Mountains of the contiguous USA. Despite this distinction, only a few field or remotely sensed studies providing glacier volume changes have been published. The current study focuses on Continental Glacier located on the northern end of the range and uses two field datasets (high-accuracy GPS surface elevation points and ice-penetrating radar transects of the glacier bed) to create a threedimensional model of glacier volume. Current surface elevations are compared with historical elevation data to calculate surface elevation change over time. An average thinning rate of $13.8 \pm 7.8 \mathrm{~m}$ $\left(0.30 \pm 0.17 \mathrm{~m} \mathrm{a}^{-1}\right)$ between 1966 and 2012 was found. Surface elevation change rates varied across the glacier, ranging from +0.30 to $-0.98 \mathrm{~m} \mathrm{a}^{-1}$. Taking into account variable melt rates across the glacier, along with a glacial volume of $72.1 \times 10^{6} \pm 10.8 \times 10^{6} \mathrm{~m}^{3}$, we estimate that Continental Glacier will be reduced in volume by $43 \%$ over the next 100 years and will disappear completely over the next $300-400$ years, if current climatic conditions persist.
\end{abstract}

KEYWORDS: applied glaciology, glacial geomorphology, glacier hydrology, glacier mass balance, ground-penetrating radar

\section{INTRODUCTION}

Mountain glaciers around the world are important contributors to streamflow and therefore act as a water resource for a wide range of uses, including irrigation, drinking water supply and hydroelectricity (Østrem, 1966; Meier, 1969; Marston and others, 1991; Yao and others, 2004; Bradley and others, 2006; Moore and others, 2009). Mountain glaciers are also sensitive to climate change and are melting rapidly, therefore drastically reducing their volume (Lemke and others, 2007) and contributing to sea-level rise (e.g. Gardner and others, 2013). They may also contribute to potential reduction in streamflow availability for water resource use once they have melted completely (e.g. Mark and Seltzer, 2003; Vuille and others, 2008; Xu and others, 2009; Kaser and others, 2010), particularly for late summer in arid regions. In the contiguous USA, rapid glacial melting linked to climate change has been noted across several mountain ranges, including the North Cascades and within Glacier National Park, Montana (Hall and Fagre, 2003; Pelto, 2006). With projected increases in temperature as a direct consequence of climate change, many mountain glaciers are expected to melt completely by 2100 (Lemke and others, 2007; Nesje and others, 2008).

In our study region, the Wind River Range of Wyoming, USA, the temperature at an elevation of $4000 \mathrm{~m}$ increased by $3.5^{\circ} \mathrm{C}$ between the mid-1960s and the early 1990s, as determined from $\delta^{18} \mathrm{O}$ evolution on an extracted ice core from Upper Fremont Glacier (southern part of the range) (Naftz and others, 2002). Another study suggests that Wind River Range glaciers will disappear as early as 2021 (Marston and others, 1991). While that study is over
20 years old, it is the only published study known to us that uses surface elevation change along with in situ measurements of ice depth to estimate the demise of glaciers in the Wind River Range.

In contrast to the projected rapid melting of many mountain glaciers, small cirque glaciers are often protected by large headwalls that allow shadows to protect against melting, and differential snow accumulation through drifting (Kuhn, 1995). In addition, climatic conditions such as snowfall are not necessarily homogeneous in mountainous regions, leading glaciers to respond differently from one basin to the next (Brown and others, 2010). Owing to these particular conditions some smaller mountain glaciers may not disappear as quickly as previously anticipated. For example, glaciers in Glacier National Park are projected to melt completely by $\sim 2030$, based on historical retreat and climate analysis (Hall and Fagre, 2003). However, Sperry Glacier was recently estimated to remain through 2080, as determined by modeling changes in mass balance under various climate change scenarios (Brown and others, 2010).

Regardless of how rapidly glaciers are melting, glacial meltwater remains a constant water resource for many populations surrounding glaciated mountain ranges. Measurements of glacier melt rates and ice volume are the two key variables needed to calculate estimates of how long a glacier will survive. To calculate ice volume, it is necessary to determine the depth of the ice and create an up-to-date ice surface elevation grid, which allows for creation of a three-dimensional (3-D) model of the glacier. Icepenetrating radar is a widely established technique for measuring ice thickness of mountain glaciers, ice caps or ice 


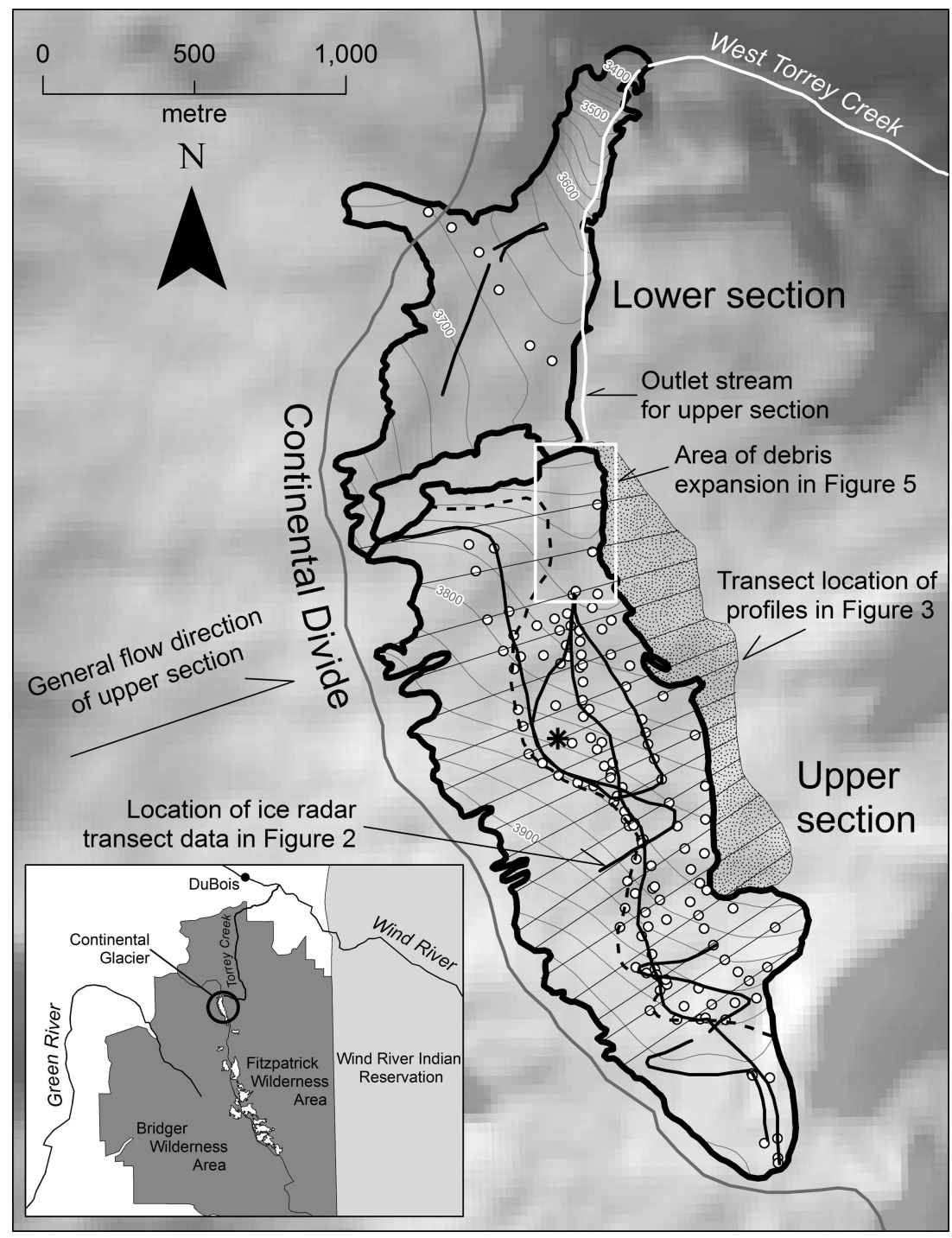

Fig. 1. Map of Continental Glacier with a hillshade background (inset shows location of Continental Glacier in relation to other Wind River glaciers). High-accuracy $(<10 \mathrm{~cm})$ GPS point locations are represented by white circles. Ice radar transects are shown as black lines. Thin black lines represent trend lines parallel to glacier flow along which interpolated points were created for the generation of the surface DEM (based on the GPS points) and bedrock DEM (based on the ice depth). Thin dashed line represents snowline altitude during fieldwork in August 2012. Terminal debris for the upper section is indicated by the speckled pattern to the east of the glacier. Elevation contours are thin gray lines (contour interval of $20 \mathrm{~m}$ with index contours labeled every $100 \mathrm{~m}$ ). Glacier outline (digitized from 2012 US National Agriculture Imagery Program (NAIP) imagery) is represented by a thick black line.

sheets (e.g. Bogorodsky and others, 1985; Nolan and others, 1995; Matsuoka and others, 2002; Bauder and others, 2003; Azam and others, 2012). While airborne ice-penetrating radar is widely used on ice sheets (Gogineni and others, 2001), ice caps (Dowdeswell and others, 2004) and large mountain glaciers (Conway and others, 2009), it remains a field-based method when applied to small glaciers in rugged terrain where steep rock walls and narrow valleys cause multiple reflections using airborne radar systems.

Recent technological improvements have made groundbased ice-penetrating radar systems lighter (Mingo and Flowers, 2010), making it easier to conduct mass-balance and ice depth measurements on remote glaciers. However, field research is still time-consuming and difficult because of environmental challenges. In some cases, wilderness restrictions that prohibit transportation by helicopter, such as those within US Forest Service wilderness areas (Zahniser, 1964), add to the difficulty in accessing glaciers. Researchers have to face these challenges to study the glaciers of the
Wind River Range, where only a handful of field studies on mass balance and/or ice depth have been published over the past few decades (e.g. Marston and others, 1991; Naftz and Smith, 1993; VanLooy and others, 2013). Despite these challenges, we present a study focusing on the mass balance, ice volume and potential remaining lifespan of Continental Glacier in the Wind River Range.

\section{STUDY AREA AND PREVIOUS RESEARCH}

Located in west-central Wyoming, the Wind River Range contains the largest concentration of glacial mass $(\sim 63$ glaciers) in the Rocky Mountains of the USA (Cheesbrough and others, 2009). This range is oriented northwest to southeast, with the Continental Divide running the length of the range (Fig. 1). The region is characterized as a dry continental climate, with orographically lifted Pacific air masses providing $\sim 100-130 \mathrm{~cm}$ of precipitation annually, and an average snowfall of $500 \mathrm{~cm}$ at the highest elevation of 
the range (Pochop and others, 1989). Field observations of air temperature on Continental Glacier during August 2012 ranged between $1^{\circ} \mathrm{C}$ at night and $15^{\circ} \mathrm{C}$ during the day, with maximum extremes of $20^{\circ} \mathrm{C}$. Snowmelt onset in the range has occurred earlier in the season since the mid-20th century (Stewart and others, 2005; Lundquist and others, 2009) and the snowpack has generally disappeared below $3000 \mathrm{~m}$ by the end of June during the 2000s (Hall and others, 2012).

The majority of glaciers are situated near the summits of the range, at elevations between 3500 and $4200 \mathrm{~m}$, with $77 \%$ located on the east side of the Continental Divide (Marston and others, 1991). Consequently, most of the glacial meltwater drains into the Wind River, which flows into the Missouri-Mississippi River system (Fig. 1). The Wind River Indian Reservation is also situated directly to the east of the Wind River Range and its population commonly uses snow and glacial meltwater for a variety of purposes, including crop irrigation and supply to fisheries for hunting and fishing (Flanagan and Laituri, 2004).

While the existence of glaciers in the Wind River Range has been documented by European pioneers since the late 19th century (Hayden, 1878; Wentworth and Delo, 1931), field research on the glaciers did not begin until 1950 (Meier, 1951). Since this initial work, only a few field measurements on a few glaciers have been published, mostly due to the challenges posed by the rugged conditions and remote access (Marston and others, 1991; Naftz and Smith, 1993; VanLooy and others, 2013). Most Wind River Glacier studies conducted over the last decade have been based either on remote sensing (Cheesbrough and others, 2009; Thompson and others, 2011) or hydrology, using streamflow and isotope data collected downstream of the glaciers (Cable and others, 2011).

Continental Glacier $\left(43^{\circ} 19^{\prime} 48^{\prime} \mathrm{N}, 109^{\circ} 41^{\prime} 27^{\prime} \mathrm{W}\right.$; $\sim 3800 \mathrm{~m}$ a.s.l.) is located on the northern end of the Wind River Range. Glacier meltwater drains into West Torrey Creek (a tributary of Torrey Creek) and eventually into the Wind River near Dubois, WY (Fig. 1). The glacier is oriented to the east-northeast and has a north-south dimension of $4 \mathrm{~km}$ and an east-west dimension of $800 \mathrm{~m}$ (VanLooy and others, 2013). The slope of the glacier is relatively low $\left(\sim 7-14^{\circ}\right)$, with the exception of a steep terminus $\left(\sim 40^{\circ}\right)$ at the north end of the glacier. There are a number of mountain peaks along the western head of the glacier, but there are no steep headwalls that could cast shadows onto the glacier. Although topographic maps list Continental Glacier as one complete glacier, it is actually divided into two sections: a larger section of $1.76 \mathrm{~km}^{2}$ at higher elevations between 3700 and $3985 \mathrm{~m}$ and a smaller section of $0.74 \mathrm{~km}^{2}$ at lower elevations between 3400 and $3785 \mathrm{~m}$. The two sections appear to respond differently to the environment (VanLooy and others, 2013).

While the glacier appears to have little to no ice flow (as indicated by the lack of movement of debris or crevasses observed on aerial imagery since 1956), using only topographic evidence the glacier would appear to flow from south to north, where the lower section flows into a steep canyon. However, further inspection shows that there are large terminal debris deposits directly to the east of the upper section, indicating a general flow direction from west-southwest to east-northeast (Fig. 1). This observation is consistent with flowlines (thin debris lines exposed by melting that show the deformation of ice through past movement), which are visible in the bare ice on aerial imagery and in the field.
Therefore, the glacier is actually wider than it is long. The main outlet stream of the upper section is located at the northeast portion of the glacier (Fig. 1). From this location, the stream flows across the eastern edge of the lower section, where it drains into West Torrey Creek.

Previous research on Continental Glacier was conducted using remote-sensing techniques to determine surface elevation and volume changes (VanLooy and others, 2013). This was achieved by differencing two digital elevation models (DEMs): a DEM derived from a United States Geological Survey (USGS) topographic map created from aerial photos in 1966, and an Advanced Spaceborne Thermal Emission and Reflection Radiometer (ASTER)-derived DEM from 2006. Results from this DEM differencing showed that the upper section of the glacier was thinning $\left(0.51 \pm 0.19 \mathrm{~m} \mathrm{a}^{-1}\right)$, whereas the lower section was essentially stagnant $\left(+0.06 \pm 0.19 \mathrm{~m} \mathrm{a}^{-1}\right)$ (VanLooy and others, 2013). In addition, the annual snowmelt pattern of the upper section observed on satellite images from 1972, 1995, 2004 and 2011 appears to begin in the center of the glacier and progress downward to lower elevations. In conjunction, the areas of greatest thinning, as noted by the 1966-2006 DEM differencing, occur within these areas of early ablation onset (VanLooy and others, 2013). During August 2011, fieldwork was conducted on Continental Glacier, but only a few GPS surface elevations and a single ice thickness measurement were obtained.

Owing to the lack of field data from 2011, a second year of fieldwork was conducted to gather more extensive glacier surface elevation and ice depth data to better constrain the current ice volume of Continental Glacier. In August 2012, an extensive GPS survey was conducted to produce a complete up-to-date DEM of the glacier surface. A survey of ice depth transects was also conducted and combined with the surface DEM to create a 3-D model of the glacier. This 3-D model was used in conjunction with calculated surface elevation change rates to determine the remaining lifespan of the glacier. As a result of the larger size and more dynamic conditions of the upper section (i.e. more rapid melt rate), as noted by the 1966-2006 DEM differencing results (VanLooy and others, 2013), this research focuses on the upper section of Continental Glacier.

\section{DATA AND METHODOLOGY}

To calculate the remaining ice volume of Continental Glacier, two measurements are required: (1) ice depth collected with an ice-penetrating radar system and (2) surface elevation collected with a differential GPS unit. The surface elevation data were required for creation of the 3-D model of glacier volume and to compare with older surface elevations (particularly from a 1966 topographic map) of the glacier, to produce a map of surface elevation change over time. Following collection of the ice-depth and surface elevation datasets, two DEMs (one for the bed and one for the glacier surface) were produced with a grid size similar to that of the older elevation datasets for consistent comparison.

\section{2 radar and GPS data collection}

Fieldwork was conducted on Continental Glacier during 10-13 August 2012. At that time $\sim 60 \%$ of the upper section of the glacier was still covered with snow/firn, while the remaining $40 \%$ was bare ice $(38 \%)$ or exposed rock debris $(2 \%)$. Snow depth data were not collected in 2012; however, the locations where snow depth data (averaging 
$2 \mathrm{~m}$ ) were collected in 2011 were melted to bare ice in August 2012. Therefore we assume the remaining snow depth from the previous winter was minimal at the time of the 2012 fieldwork.

A portable impulse radar system from Blue Systems Integration Ltd (Mingo and Flowers, 2010) was used for common-offset surveys to measure ice thickness along continuous transects across the glacier (Fig. 1). The radar system includes a monopulse radar transmitter (Narod and Clarke, 1994), two antennas, and a digitizer that integrates data acquisition and storage, and provides real-time visual display of ice depth. For the antennas, a nominal center frequency of $10 \mathrm{MHz}$ is used for sounding the glacier; assuming the resolution is limited to one-quarter of the wavelength, the vertical resolution is $\sim 4 \mathrm{~m}$ (Mingo and Flowers, 2010). A sampling rate between 3 and $5 \mathrm{~s}$ allows depth at point locations to be measured every $3 \mathrm{~m}$ while traversing the glacier at low speed. Horizontal locations of each depth were recorded by a low-accuracy GPS unit (accuracy $<15 \mathrm{~m}$ ) incorporated into the receiver.

The radar survey resulted in six continuous transects of the glacier, with efforts to conduct transects both perpendicular and parallel to glacier flow (Fig. 1). The nonuniform coverage was due to the presence of crevasses in the accumulation area, making much of it inaccessible. While the upper section of Continental Glacier was the focus of this study, one transect was also completed across the lower section.

Static surface elevation point data were collected using high-accuracy Trimble ${ }^{\mathrm{TM}}$ GeoXH and Trimble ${ }^{\mathrm{TM}}$ GeoXT handheld GPS units. Both GPS units have a horizontal accuracy $<10 \mathrm{~cm}$ and a vertical accuracy $<1 \mathrm{~m}$ after differential corrections are applied using nearby base stations (Dubois and Moose, WY, at a distance of 20 and $85 \mathrm{~km}$, respectively). For the surface elevation data, four parallel traverses were made across the glacier with the two GPS units spaced $\sim 250 \mathrm{~m}$ apart with points collected every $\sim 100 \mathrm{~m}$, yielding a total of 142 points. The GPS points were based on the World Geodetic System 1984 ellipsoidal elevation (WGS84) horizontal datum, with vertical measurements based on the Earth Gravitational Model 1996 (EGM96) geoid. As with the ice-penetrating radar transects, certain portions in the accumulation area of the glacier were avoided because of safety concerns. The GeoXH GPS unit was also used to collect sample points along the icepenetrating radar transects to adjust the ice radar GPS elevations and estimate their associated accuracy $(<1 \mathrm{~m})$.

\section{Historical elevation data}

A USGS topographic map (1:24 000) of Continental Glacier produced from September 1966 aerial photographic stereopair images was used to create a DEM for comparison with the 2012 surface elevation data. The DEM was generated from a series of elevation points digitized from the contours (every $50 \mathrm{~m}$ ) on the topographic map (VanLooy and others, 2013). Each digitized contour was then interpolated using an ordinary kriging method (Kitanidis, 1997). A Gaussian model with 15 lags and a $90 \mathrm{~m}$ lag size was the best fit for the semivariogram in the kriging process. The final DEM was produced with a spatial resolution of $1 \operatorname{arcsec}(30 \mathrm{~m} \times 22 \mathrm{~m})$ and was readjusted to the WGS84 horizontal datum, with elevation converted from feet to meters (VanLooy and others, 2013). Uncertainty within the topographic map is assumed to be within half the vertical distance between contour intervals, which in this case is $6.1 \mathrm{~m}$. The absolute accuracy of the DEM was analyzed by comparing DEM elevations with GPS elevations collected in the field on bedrock around the edge of the glacier during August 2011, which indicated an offset of $2.9 \pm 3.4 \mathrm{~m}$, with the 1966 DEM being higher than the GPS elevations (VanLooy and others, 2013). Comparing the 1966 DEM with six GPS points collected off-glacier for this study during August 2012, the offset between the vertically unadjusted DEM and the GPS points also indicated that the DEM was higher by $2.8 \pm 2.3 \mathrm{~m}$. Owing to the consistency in absolute vertical accuracy analysis between VanLooy and others, (2013) and this study, the 1966 DEM used by VanLooy and others (2013) was adjusted for the $2.9 \mathrm{~m}$ offset and used for the current study.

\section{2 surface DEM generation}

The differentially corrected (Trimble ${ }^{\mathrm{TM}}$ ) GPS surface elevations collected in 2012 were used in conjunction with edgeof-glacier bedrock elevations determined from the adjusted 1966 DEM to interpolate a surface DEM of the glacier for 2012. A preliminary DEM interpolation of these points showed that the limited number of GPS points collected in the field resulted in a poorly interpolated DEM because the shape of the glacier surface is not covered adequately by these few points. However, the continuous transects from the lower-accuracy radar GPS show that the glacier generally has a parabolic surface shape parallel to the glacier flow direction, which was confirmed visually through field observations (Fig. 2). Therefore, to produce more elevation points and generate a more accurate DEM representing the surface shape of the glacier, parabolic trend lines were fitted along the high-accuracy GPS points parallel to the flow direction of the glacier (Fig. 1). Each trend line was spaced $\sim 100 \mathrm{~m}$ apart, as designated by the frequency of the GPS point collection. With the edge-of-glacier bedrock elevations as 'tie points' for the trend lines, new elevation points were interpolated along the trend lines every $\sim 30 \mathrm{~m}$. On the eastern edge of the glacier, the bedrock beyond the terminus debris was used as the 'tie points' due to the possible instability of the debris. However, trend-line elevations were not interpolated at the southern end of the glacier due to the surface geometry.

At its southern end, the glacier rises to its highest elevation and flattens along a ridgeline. This topography is not well modeled by the parabolic shape used for the rest of the glacier; therefore, it was necessary to use only the collected GPS points for the generation of the DEM at this location. However, a limited number of high-accuracy Trimble $^{\mathrm{TM}}$ GPS points were collected at this location and therefore the lower-accuracy elevations from the radarembedded GPS were used as supplementary data. To obtain a higher vertical accuracy, the low-accuracy ice radar GPS and high-accuracy Trimble ${ }^{\mathrm{TM}}$ GPS points were compared where overlap occurred. Overall across the glacier, 16 points overlapped (within $3 \mathrm{~m}$ horizontally), resulting in an offset of $0.31 \pm 2.62 \mathrm{~m}$, and the ice radar GPS was higher in elevation. This offset was subtracted from each radar GPS point and the points were used only where there was a lack of high-accuracy Trimble ${ }^{\text {TM }}$ GPS points. Overall, $18 \%$ of the elevation points came from the radar GPS.

Ordinary kriging was used to interpolate the new surface points, resulting in a new 2012 DEM with a spatial resolution of 1 arcsec $(30 \mathrm{~m} \times 22 \mathrm{~m})$ and a root-mean-square error (RMSE) of $1.88 \mathrm{~m}$. The 2012 DEM was also compared 

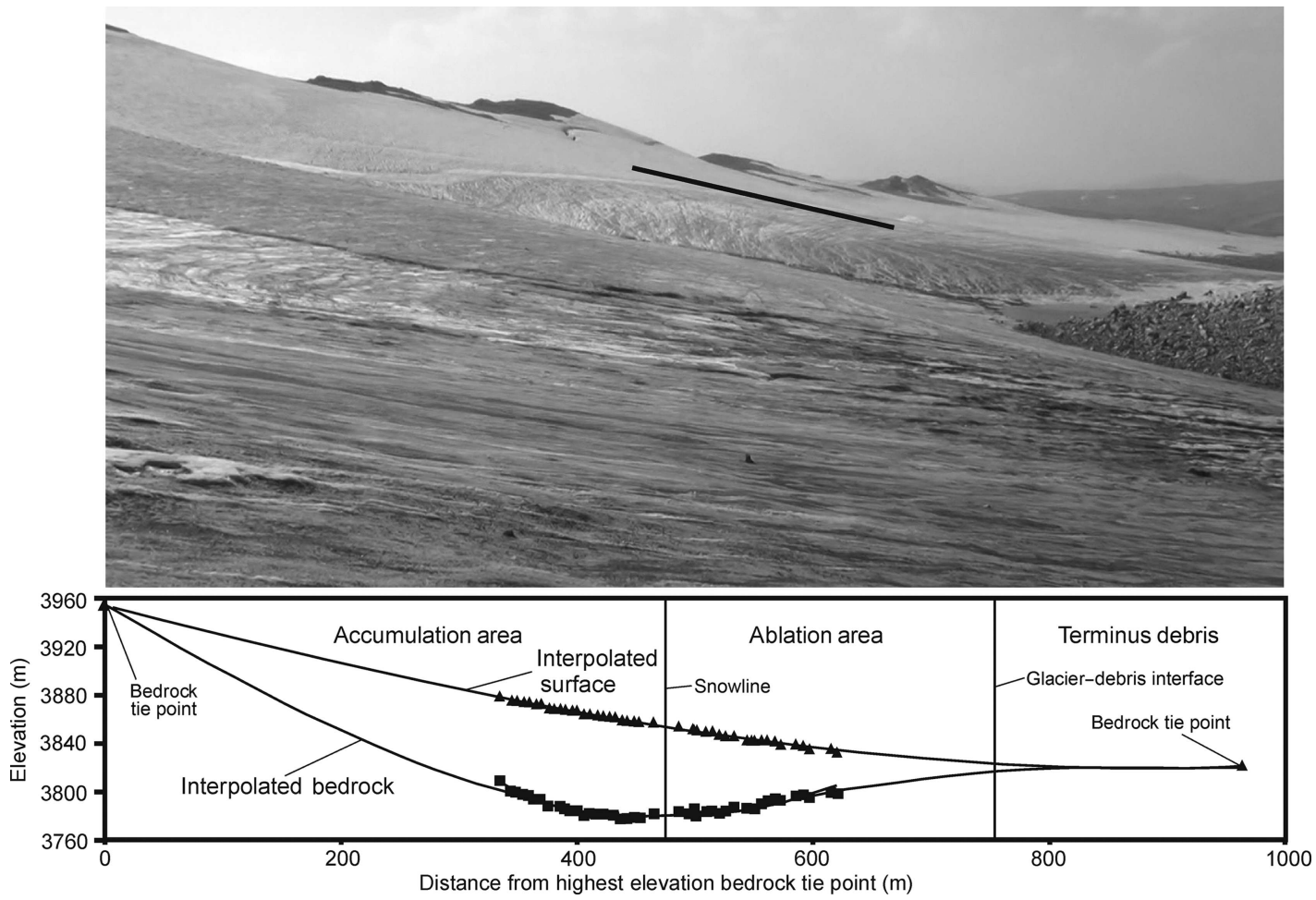

Fig. 2. Parabolic trend lines fitting surface elevations (black triangles) of the adjusted ice radar GPS locations and ice thickness (black squares) from the ice radar transect parallel to glacier flow. Division between the accumulation and ablation areas is an approximation based on the late-summer snowline at the time of the fieldwork. The black line on the photograph (view looking north) shows the approximate location of the transect (also shown in Fig. 1).

with the remaining high-accuracy GPS points (e.g. points collected while following the ice radar transects and not included in the DEM interpolation process) as another measure of accuracy. The results of this analysis indicated that the 2012 kriged DEM was interpolated, on average, $2.52 \pm 3.31 \mathrm{~m}$ too high for the absolute elevation. The 2012 DEM was then adjusted by subtracting this value from the entire DEM.

\section{2 bedrock DEM generation}

The bedrock DEM beneath the ice surface was generated using the same method as for the glacier surface DEM. The same trend-line locations parallel to glacier flow were used in the interpolation process for ice thickness in areas where ice radar measurements were lacking. However, uncertainty in the interpolated ice thickness points will increase along trend lines where only one radar transect is present. Therefore, to prevent introducing more uncertainty in the final bedrock DEM, ice thickness was interpolated only where two or more ice radar transects crossed perpendicular to the trend lines. Mapping bedrock elevations first involved extracting ice thickness at each transect point and then subtracting the ice thickness from the newly created 2012 surface DEM. Radar two-way travel time was converted to ice thickness assuming constant radar electromagnetic waves travel into the ice at $1.68 \times 10^{8} \mathrm{~m} \mathrm{~s}^{-1}$ (Mingo and Flowers, 2010). The bedrock elevations were used with the edge-ofglacier elevations for interpolating bedrock elevations in locations where ice radar transects were not available.

While verifying glacier bed shape is difficult because it is not possible to confirm glacier morphology visually, radar profiles of the bed following the transects that run parallel to glacier flow generally indicate a concave (or parabolic) shape, consistent with a typical cirque glacier morphology (Figs 2 and 3). The concave pattern of the glacier bed continued to appear as the other ice thicknesses were plotted along their corresponding trend lines. However, the concave pattern flattens out as it nears the terminus (within $\sim 250 \mathrm{~m}$ ) where ice depth becomes relatively small ( $\sim 20-40 \mathrm{~m})$.

Bedrock elevations located away from the radar profiles were interpolated using the best-fitting trend line of the known bedrock and edge-of-glacier elevation points. The majority of these were third-order polynomial equations. Interpolated points were spaced $30 \mathrm{~m}$ apart along the flowlines and each flowline was separated by $\sim 100 \mathrm{~m}$. The interpolated bedrock points along with known bedrock elevations determined from the original radar profile depths were used in ordinary kriging (RMSE $4.38 \mathrm{~m}$ ) to produce a final bedrock DEM with a spatial resolution matching the two surface DEMs ( 1 arcsec; $30 \mathrm{~m} \times 22 \mathrm{~m}$ ). The single ice thickness measurement collected with the stationary radar system in August 2011 allowed for a comparison with the interpolated thicknesses from the 2012 data. The August 2011 measurement located near the center of the glacier indicated a depth of $100 \pm 4 \mathrm{~m}$, which is in agreement with the interpolated line for the 2012 ice thickness along that particular flowline (Fig. 3). This result confirms that the interpolation method is appropriate for creating the bedrock DEM.

\section{Analytical process and uncertainty analysis}

Following the geodetic method (Fountain and others, 1997), the 2012 DEM of glacier surface was differenced from the 1966 DEM (using the Raster Calculator Tool in Environmental Systems Research Institute's (ESRI) ArcGIS ${ }^{T M}$ ), providing surface elevation change values at each cell in the DEM. These cell values were multiplied by the area of 


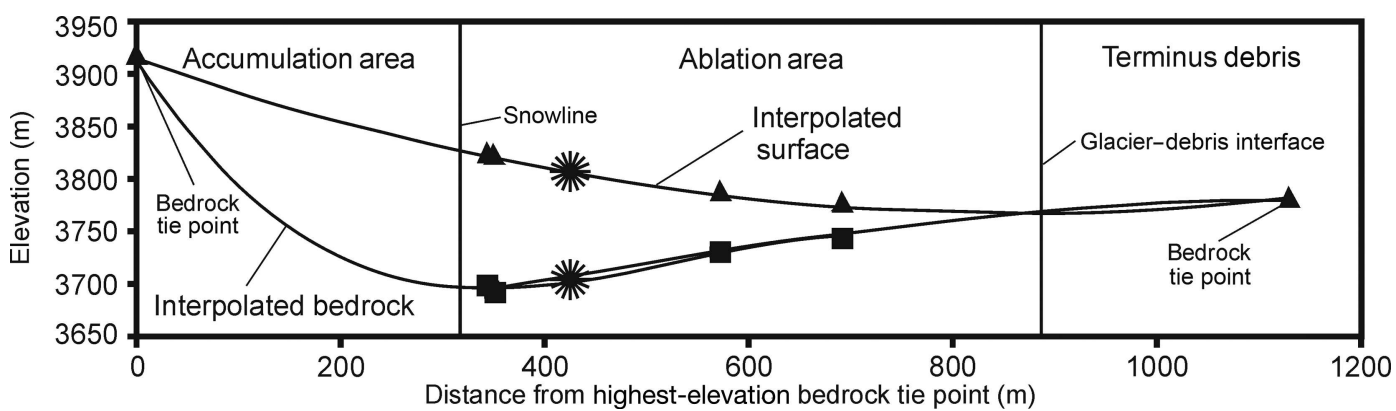

Fig. 3. Parabolic trend lines fitting surface elevations (black triangles) of the adjusted ice radar GPS and ice depth (black squares) along a transect parallel to glacier flow. The two asterisks indicate the surface elevation and depth (on the graph) and location (in Fig. 1) of the August 2011 ice radar measurement.

the individual cells (in this case $30 \mathrm{~m} \times 22 \mathrm{~m}$ in the Universal Transverse Mercator (UTM) coordinate system) and summed to produce a final volume change between 1966 and 2012. The resulting volume change was divided by the area of the glacier $\left(1.76 \mathrm{~km}^{2}\right.$ as determined from the 1966 topographic map) to calculate the final surface elevation change. Similarly, the remaining volume of the glacier was determined by differencing the 2012 bedrock DEM from the 2012 glacier surface DEM. The total volume of the glacier was then calculated by multiplying the cell size $(30 \mathrm{~m} \times 22 \mathrm{~m})$ by the elevation difference results for each cell, and finally summing these results.

There are five sources of uncertainty in the resulting surface elevation change and total volume calculations, all previously described: (1) DEM offset analysis as compared with the GPS points $\left(\delta_{a}=3.31 \mathrm{~m}\right) ;$ (2) RMSE from the interpolation process $\left(\delta_{b}=1.88 \mathrm{~m}\right) ;$ (3) topographic map uncertainty $\left(\delta_{c}=6.10 \mathrm{~m}\right)$; (4) vertical uncertainties for the high-accuracy GPS $\left(\delta_{d}=0.10 \mathrm{~m}\right)$; and (5) vertical uncertainties for the radar GPS $\left(\delta_{e}=2.62 \mathrm{~m}\right)$. To calculate the total uncertainty $\left(\delta_{q}\right)$ for either surface elevation change or total remaining glacier volume, the uncertainty components were summed in quadrature (Taylor, 1982) using

$$
\delta_{q}=\sqrt{\left\{\left(\delta_{a}\right)^{2}+\left(\delta_{b}\right)^{2}+\left(\delta_{c}\right)^{2}+\left(\delta_{d}\right)^{2}+\left(\delta_{e}\right)^{2}\right\}}
$$

The surface elevation change uncertainty was then divided by the number of years (46) between the two datasets for an uncertainty value of $\pm 0.17 \mathrm{~m} \mathrm{a}^{-1}$.

Uncertainty in the ice volume includes all of the uncertainty components from the 2012 DEM (i.e. $\delta_{a \prime} \delta_{b}$ $\delta_{c}, \delta_{d}$ and $\delta_{e}$ ) along with the vertical uncertainty in the ice radar returns $( \pm 4 \mathrm{~m})$. This uncertainty calculation, which was also summed in quadrature, is first expressed in meters (as all components of potential uncertainty are deduced from vertical offsets), but was then converted to a volume uncertainty by multiplying by the area of the glacier $\left(1.76 \mathrm{~km}^{2}\right)$. The result has a total uncertainty in ice volume of $\pm 10.8 \times 10^{6} \mathrm{~m}^{3}$.

\section{RESULTS AND DISCUSSION}

\section{Surface-elevation changes}

The difference calculation between the 1966 and 2012 DEMs resulted in an average surface lowering of $13.8 \pm 7.8 \mathrm{~m}$ $\left(0.30 \pm 0.17 \mathrm{~m} \mathrm{a}^{-1}\right)$ for the upper section of Continental Glacier, with rates varying across the glacier between +0.32 and $-0.98 \mathrm{ma}^{-1}$. These estimates of glacier melting are in contrast to those for other Wind River Range glaciers, which are thinning at faster rates (i.e. Dinwoody: $0.88 \mathrm{~m}$ w.e. $\mathrm{a}^{-1}$ between 1958 and 1983; Fremont: $0.93 \mathrm{~m} \mathrm{a}^{-1}$ in the early 1990s) (Marston and others, 1991; Naftz and Smith, 1993). This emphasizes the point that glacial changes can vary from basin to basin, even within the same mountain range (Brown and others, 2010).

The greatest glacial thinning on the upper section of Continental Glacier $\left(\sim 1 \mathrm{~m} \mathrm{a}^{-1}\right)$ occurred in three patches located on the central and southern portions of the glacier (Fig. 4). This thinning pattern is interesting as the southern thinning patches occur at high elevations on the glacier. Previous analysis of aerial photographs and satellite imagery over several decades shows that summer ablation consistently begins at three locations near the center and southern end of the glacier, as indicated by visible bare ice versus snow cover on the imagery (VanLooy and others, 2013). This study confirms the presence of the thinning patches and their relationship with the locations of annual ablation onset across the glacier (Fig. 4).

A surface elevation change calculation was carried out between the 2006 ASTER DEM and the 2012 DEM. This was conducted using the same method as for the 1966 and 2012 DEM comparison; however, it was discovered through the resulting difference image that the 2006 ASTER DEM had significant elevation errors in the southern thinning patches. While the original 1966-2006 DEM difference showed plausible thinning rates in the southern thinning patches of $2.9 \mathrm{~m} \mathrm{a}^{-1}$ at the extreme (VanLooy and others, 2013), the surface-elevation changes between 2006 and 2012 at the same locations indicated substantial thickening of up to $12 \mathrm{~m} \mathrm{a}^{-1}$. This indicated that the 2006 ASTER-derived DEM was the source of the error as these locations were represented by elevations that were too low compared with the 2012 high-accuracy GPS elevations collected in the field, and it is highly unlikely that the glacier thickened by $12 \mathrm{~m} \mathrm{a}^{-1}$ between 2006 and 2012. Therefore, the 2006 DEM was discarded in the surface elevation change analysis in this study, and we emphasize the need for caution when using ASTER-derived DEMs in glacier surface change calculations (Nuth and Kääb, 2011). For these reasons, the current study provides more reliable average glacier thinning rates for the upper section of Continental Glacier for 1966$2012\left(0.30 \pm 0.17 \mathrm{~m} \mathrm{a}^{-1}\right)$ than those for 1966-2006 $\left(0.51 \pm 0.19 \mathrm{~m} \mathrm{a}^{-1}\right)$ reported by VanLooy and others (2013).

\section{Glacier area change analysis}

Aerial photographs taken by the United States Department of Agriculture (USDA) for the National Agriculture Imagery 


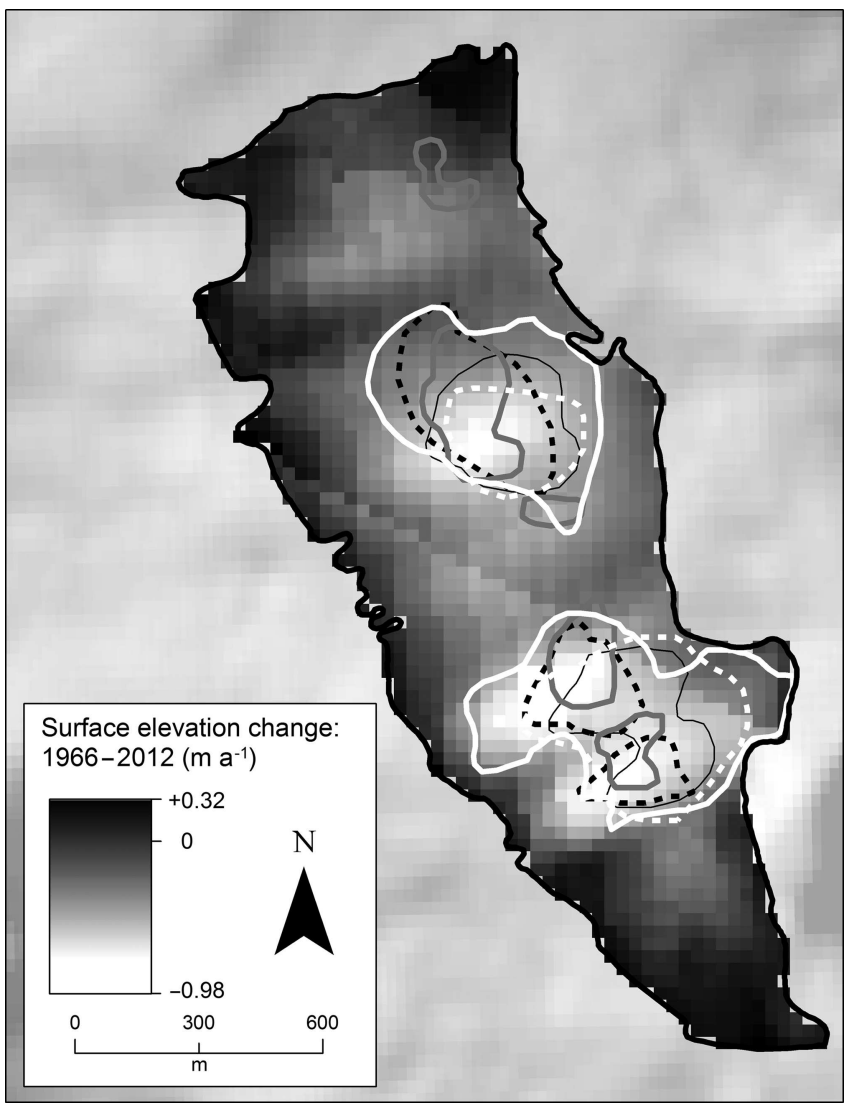

Fig. 4. Surface elevation change of the upper section of Continental Glacier between 1966 and 2012. Lines indicate the location of ablation onset for 1956 (thick white line), 1972 (thick white dashed line), 1995 (thick gray line), 2004 (thick black dashed line) and 2011 (thin black line)

Program (NAIP) along with Landsat multispectral scanner (MSS) and thematic mapper (TM) imagery were obtained for an analysis of total glacier area change. The NAIP imagery is typically collected near the end of a hydrological year (end of summer) when most of the previous winter's snow is expected to have melted from the glacier. At this time, the equilibrium line of the glacier is theoretically equivalent to the snowline. Also, the Landsat images for August and September provided a more accurate representation of glacier area, unimpeded by snow cover. However, for six of the ten years of imagery (aerial photograph: 15 September 1956; MSS image: 6 August 1972; TM image: 20 August 1995; TM image: 4 August 2004; aerial photograph: July 2009; and ground photograph: 6 August 2011) snow from the previous winter still covered much of the glacier. The only areas during these years in which bare ice was visible were the same thinning patch locations noted in the surface elevation change difference image (Fig. 4). Two of the years (aerial photographs: midSeptember 2006 and late July 2012) showed substantial melting of the previous winter's snowpack as approximately half of the glacier was exposed as bare ice. The imagery from the other two years (aerial photographs: September 1980 and 1983) showed fresh snowfall, making it difficult to distinguish the extent of the summer ablation areas.

An analysis of glacier area changes was conducted by digitizing the glacier outline over time (1956-2012) from the aerial photographs ( $1 \mathrm{~m}$ resolution) and Landsat imagery (30 $\mathrm{m}$ resolution). Minimal changes occurred around most of the glacier's edge (reduced in size by $<3 \%$ over the 56 year period), and most of the change occurred near the highest point of the glacier at the southern end where topography is broad and flat. Analysis of rock debris at the terminus and along other portions of the glacier shows negligible change. The only consistent change in debris was along a linear pattern stretching from the northeast portion of the glacier. This area of debris appears to grow substantially (extending $465 \mathrm{~m}$ ) between 1994 and 2012 (Fig. 5). However, the debris area (including visible large boulders) extends but preserves its original shape over this time period, suggesting that it is being exposed as the glacier thins. The lack of substantial change in glacier area along with this 'growing' debris line (despite the lack of boulder or other debris movement) suggests that Continental Glacier is thinning vertically without shrinking horizontally, acting more as a remnant ice field or stagnant glacier.
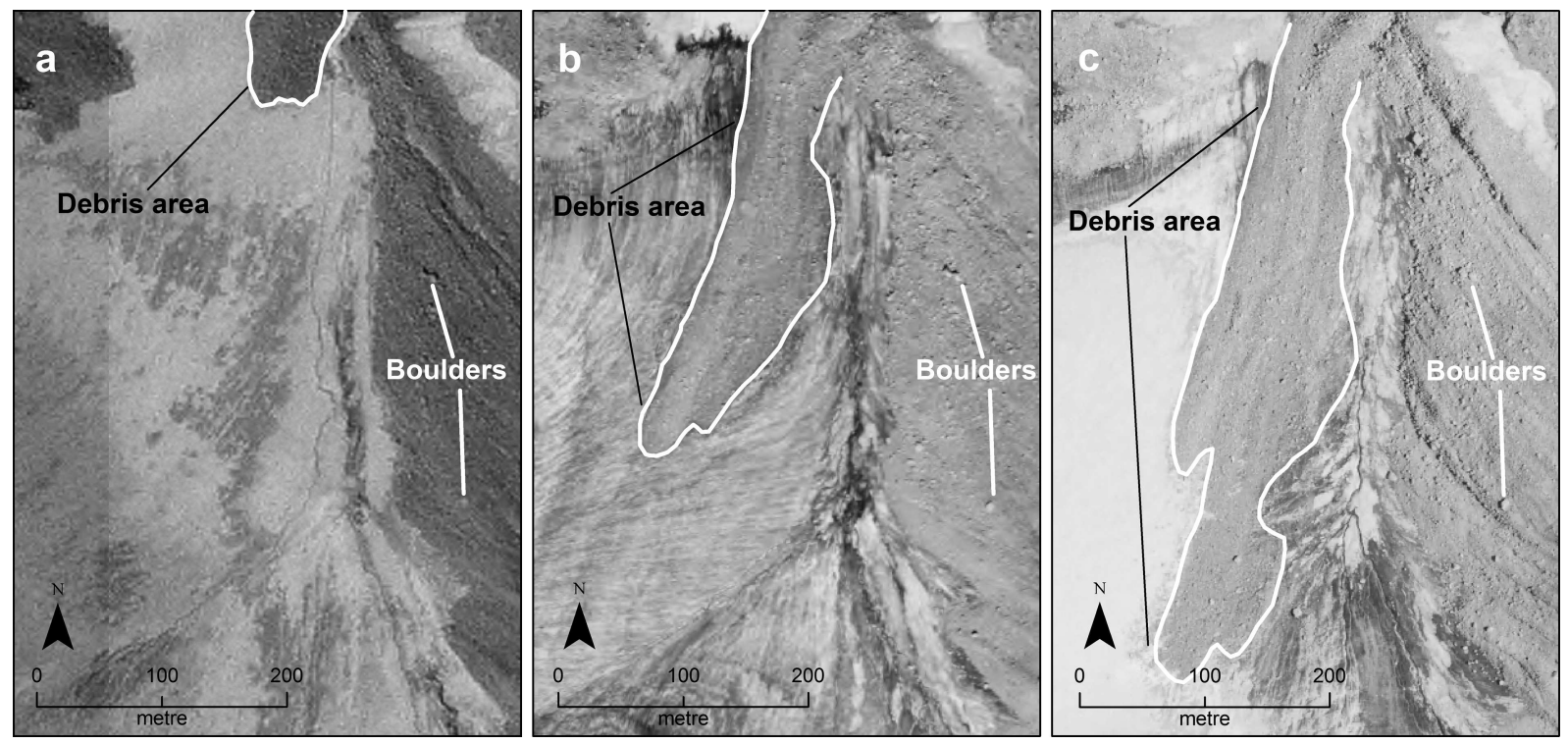

Fig. 5. NAIP imagery of the exposed debris evolution caused by progressive glacier melting along the northeast portion of the glacier: (a) 1994, (b) 2006 and (c) 2012. 

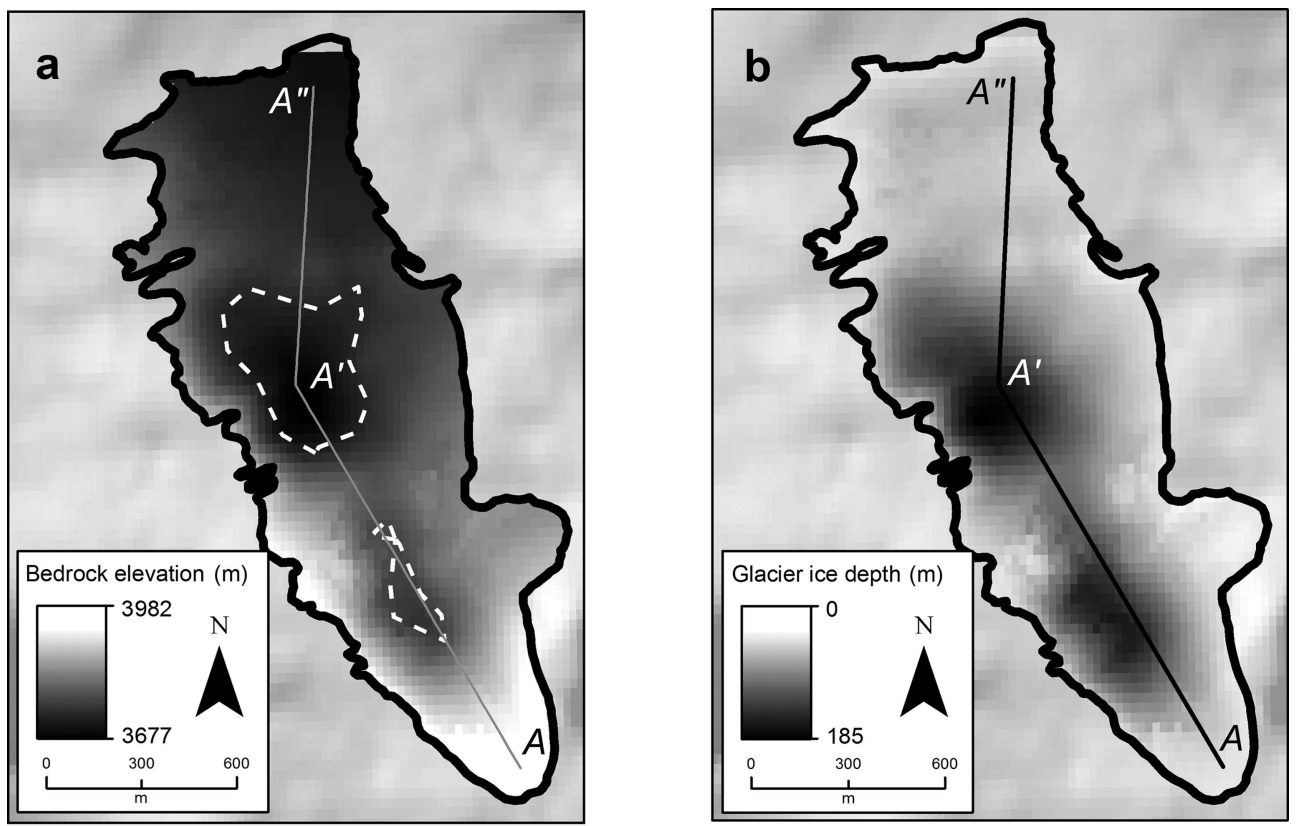

C

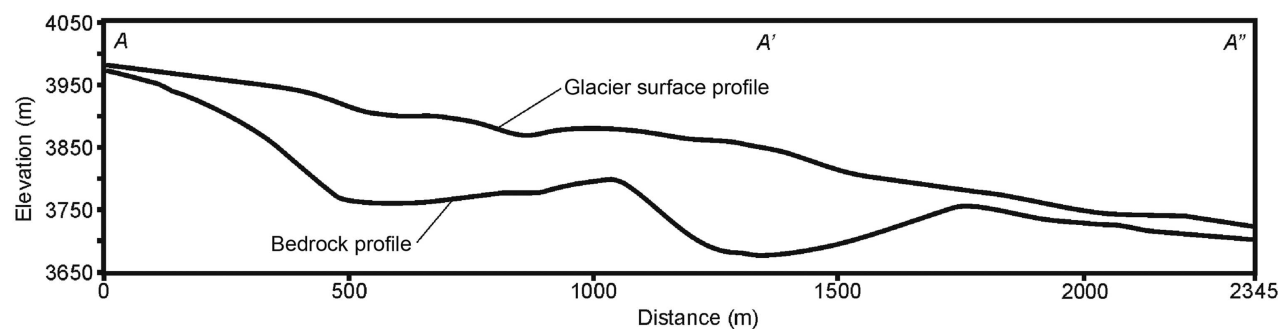

Fig. 6. (a, b) Map of (a) bedrock elevation and (b) ice depth from glacier surface. (c) Transect profile highlighting cyclopean staircase and glacier surface. Estimated tarn lake areas are noted by dashed lines in (a).

\section{Glacier bed morphology and total remaining ice volume}

The bedrock beneath the glacier is composed of two cirque depressions with a steep headwall located generally to the east side of the glacier (Fig. 6a). A south-to-north transect of the glacier bed shows that the bedrock has a profile similar to a cyclopean staircase in which the two cirques step down from higher to lower elevations (Fig. 6c). This profile fits the pattern of other previously glaciated cirques surrounding Continental Glacier and throughout the Wind River Range, visible on topographic maps.

The glacier thickness follows a similar pattern to the shape of the base of the glacier (e.g. two deep spots in proximity to the two cirques) (Fig. 6b). The greatest depth of the glacier was $\sim 184 \mathrm{~m}$ in the northern cirque and $\sim 150 \mathrm{~m}$ in the southern cirque. Beyond the two cirques, the glacier is relatively thin: $33 \%$ of the glacier is $<20 \mathrm{~m}$ deep, located primarily around the periphery, and $26 \%$ is between 20 and $40 \mathrm{~m}$ deep. The remaining $41 \%$ of the glacier includes the two cirques between 40 and $184 \mathrm{~m}$. An analysis was conducted on the bedrock DEM to determine the possible formation of tarn lakes if the glacier were to melt completely and the two cirques were to fill with water (Fig. 6a). In this event, two lakes would form, covering areas of $0.16 \mathrm{~km}^{2}$ (for the northern cirque) and $0.03 \mathrm{~km}^{2}$ (for the southern cirque). While the lakes would be only a fraction of the glacier in terms of potential water storage, they would still act as reservoirs for snowmelt and rainfall for downstream water use.
The total ice volume of the upper section of Continental Glacier in August 2012 is $72.1 \times 10^{6} \pm 10.8 \times 10^{6} \mathrm{~m}^{3}$, representing $\sim 64.9 \times 10^{6} \pm 9.7 \times 10^{6} \mathrm{~m}^{3}$ meltwater for potential water resource use. Given the known volume of the glacier and the surface elevation lowering rates between 1966 and 2012, an estimation of the expected remaining lifespan of the upper section of Continental Glacier was calculated. The glacier volume at each cell (of the DEM difference) was divided by the average surface elevation change rates for the corresponding cells across the entire glacier. This resulted in a glacier map of the number of years until the ice thickness reaches zero (Fig. 7). Given the amount of glacial ice and the relatively slow thinning rate, the glacier is expected to reduce in volume by $24 \%$ over the next 50 years, using this simple thinning rate model. Over the next 100 years, the glacier is estimated to reduce in volume by $43 \%$ and will bifurcate into multiple ice masses. The remaining glacial mass is estimated to disappear in $\sim 300-400$ years.

There are a number of assumptions with this model. First, only the surface elevation change values indicating thinning were used, as any positive surface elevation changes would indicate unlikely continued accumulation. However, thickening composed only $10 \%$ of the glacier and is present around the periphery where the majority of elevation changes between the 1966 and 2012 DEMs are small and within the uncertainty. Second, these estimates do not take into account dynamic changes in melting rates as the glacier shrinks. Finally, the estimates do not take into account any 


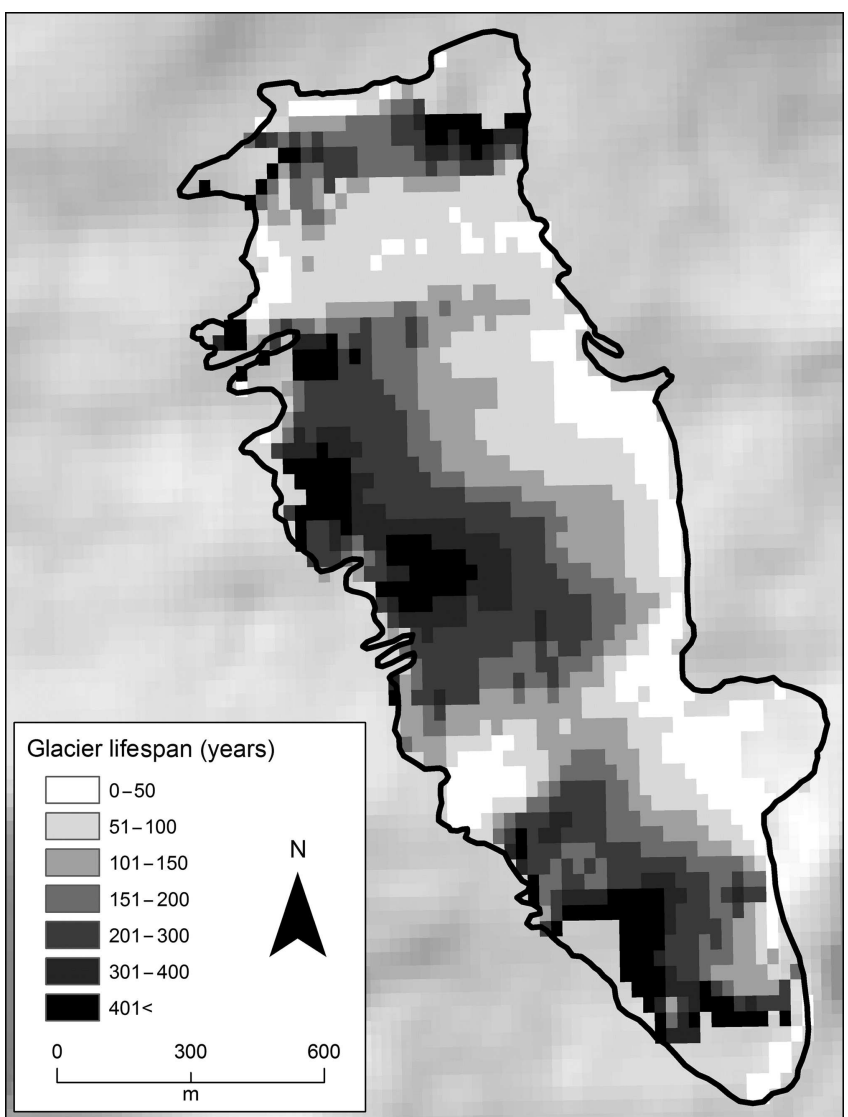

Fig. 7. Lifespan estimation for Continental Glacier. Areas with missing values were due to either positive surface elevation change values (only negative values were used for determining remaining glacial lifespan) or errors within the bedrock and/or surface DEMs leading to inverted ice depth, particularly in locations where the ice thickness was small (near zero), such as at the southern end of the glacier.

projected climatic change over the next 400 years. Instead, the surface elevation change rate (directly related to climatic conditions) used for this analysis is the average rate measured between 1966 and 2012. It is possible that a more recent surface elevation change rate (e.g. between 2006 and 2012) could lead to different results (likely an acceleration of the melting rate). However, even if the melting rates of the glacier were to triple, our estimates indicate it would still take $\sim 100-134$ years before the glacier melted completely.

This study also highlights the difficulties in making regional glacier lifespan estimates for the entire mountain range, since differential melting is observed both within an individual glacier and between different glaciers. For example, Marston and others (1991) found that Dinwoody Glacier had $69 \times 10^{6} \mathrm{~m}^{3}$ w.e. remaining, and that it was melting at a rate of $\sim 0.88 \mathrm{~m}$ w.e. $\mathrm{a}^{-1}$. Given these values (along with the area of the glacier, $2.91 \mathrm{~km}^{2}$ ), a direct calculation of the remaining lifespan of the glacier, assuming a constant melt rate, is 27 years. Applying the same method to Continental Glacier, it will take 123 years to melt completely (using the 46 year average melt rate of $0.30 \mathrm{~m} \mathrm{a}^{-1}$ ). This represents even less time if our projected melt rates were tripled using differential melt rates across the glacier (134 years). However, the lifespan results using either method (averaged melt rates versus variable melt rates) for Continental Glacier are substantially longer than the extrapolated projection by Marston and others (1991) of 30 years for all Wind River Glaciers. This study emphasizes that glacier mass-balance variability in relation to ice thickness at coincident locations needs to be taken into account when attempting to project remaining glacier lifespan.

\section{2 observations of the lower section}

While most of this study focuses on the upper section of Continental Glacier, due to its larger size and dynamic characteristics compared with the lower section analyzed by VanLooy and others (2013), some data were collected and a few observations were made in 2012 concerning the lower section. One ice radar transect and high-accuracy GPS survey was conducted across the lower section (Fig. 1). The ice thickness measurements indicate that the lower section is generally shallow, with an average thickness of $17 \mathrm{~m}$, ranging between 0 and $30 \mathrm{~m}$. Considering this average depth over the area of the lower section $\left(0.74 \mathrm{~km}^{2}\right)$ the amount of remaining glacial mass for this section is estimated to be $12.6 \times 10^{6} \pm 10.8 \times 10^{6} \mathrm{~m}^{3}\left(11.3 \times 10^{6} \pm 9.7 \times 10^{6} \mathrm{~m}^{3}\right.$ w.e. $)$. However, it should be noted that this is a first-order estimate of remaining glacial volume as a lack of ice depth data did not allow for detailed analysis.

Although only six GPS points were collected across the lower section, these points were differenced with the 1966 DEM to determine an average elevation change for the point locations. The elevations between 1966 and 2012 showed no significant change as these locations on the lower section of the glacier actually thickened by $0.06 \pm 0.19 \mathrm{~m} \mathrm{a}^{-1}$.

Visual observations showed that the only portion of the lower section that had bare ice was located at the terminus, where the topography is steeper $\left(\geq 40^{\circ}\right)$ at the lowest elevations of the glacier $(\sim 3370 \mathrm{~m})$. The remainder of the lower section (91\%) is at elevations between 3600 and $3800 \mathrm{~m}$, with similar slopes as the upper section $\left(8-14^{\circ}\right)$, and was still snow-covered above $3540 \mathrm{~m}$ in August 2012. This is in contrast to the upper section, which had $\sim 38 \%$ bare ice. The contrast in surface elevation change and snowcover characteristics between the upper and lower sections raises questions because these two sections are changing at different rates despite their proximity, similar slopes and same general aspect and the fact that they are located within the same basin.

\section{CONCLUSIONS}

Despite being represented as one glacier, Continental Glacier should actually be viewed as two separate glaciers responding differently to the environment. Owing to its substantially larger size and significant changes noted in a previous study (VanLooy and others, 2013), the upper section of Continental Glacier was chosen for detailed analysis of surface elevation changes and remaining glacial volume in order to estimate the remaining time it will exist as a water resource. We observed $72.1 \times 10^{6} \pm 10.8 \times 10^{6} \mathrm{~m}^{3}$ remaining glacial volume $\left(\sim 64.9 \times 10^{6} \pm 9.7 \times 10^{6} \mathrm{~m}^{3}\right.$ w.e. $)$. The glacier is thinning at an average rate of $0.30 \pm 0.17 \mathrm{~m} \mathrm{a}^{-1}$ $\left(24.3 \times 10^{6} \mathrm{~m}^{3}\right.$ loss of glacial volume since 1966$)$, with surface changes ranging from -0.98 to $+0.32 \mathrm{~m} \mathrm{a}^{-1}$. In addition, the glacier area reduced by $<3 \%$ from 1956 to 2012. This observation highlights the importance of combining surface elevation changes with area changes to represent total glacier changes. If the rates of surface-elevation change on Continental Glacier were to persist, it is estimated that 
$43 \%$ of the glacier would melt out over the next 100 years and the glacier would disappear completely within 300-400 years. Although these estimates are based on linear average thinning between 1966 and 2012 and do not take into account future climate projections, even if glacial melting rates were to triple it is estimated that it would take $>130$ years for the glacier to melt completely.

\section{ACKNOWLEDGEMENTS}

This work was partially supported by NASA grant NNX10AH20G and by a Faculty Seed Money Award from the Office of the Vice President for Research at the University of North akota. Clément Miège is supported by a NASA ESS fellowship. We thank Sergey Molodtsov, Tatiana Molodtsova and David Buttz for assistance in the field. We also thank the National Forest Service for permission to conduct the fieldwork within the Bridger and Fitzpatrick Wilderness Areas, as well as Blucher Creek Outfitters and Derrick Sellergren for support and assistance in traveling to the field site. Finally, we thank two reviewers for comments which improved the quality of the manuscript.

\section{REFERENCES}

Azam MF and 10 others (2012) From balance to imbalance: a shift in the dynamic behaviour of Chhota Shigri glacier, western Himalaya, India. J. Glaciol., 58(208), 315-324 (doi: 10.3189/ 2012JoG11J123)

Bauder A, Funk M and Gudmundsson GH (2003) The ice-thickness distribution of Unteraargletscher, Switzerland. Ann. Glaciol., 37, 331-336 (doi: 10.3189/172756403781815852)

Bogorodsky VV, Bentley CR and Gudmandsen PE (1985) Radioglaciology. D. Reidel, Dordrecht

Bradley RS, Vuille M, Diaz HF and Vergara W (2006) Threats to water supplies in the tropical Andes. Science, 312(5781), 1755-1756 (doi: 10.1126/science.1128087)

Brown J, Harper J and Humphrey N (2010) Cirque glacier sensitivity to 21st century warming: Sperry Glacier, Rocky Mountains, USA. Global Planet. Change, 74(2), 91-98 (doi: 10.1016/ j.gloplacha.2010.09.001)

Cable J, Ogle K and Williams D (2011) Contribution of glacier meltwater to streamflow in the Wind River Range, Wyoming, inferred via a Bayesian mixing model applied to isotopic measurements. Hydrol. Process., 25(14), 2228-2236 (doi: 10.1002/hyp.7982)

Cheesbrough K, Edmunds J, Tootle G, Kerr G and Pochop L (2009) Estimated Wind River Range (Wyoming, USA) glacier melt water contributions to agriculture. Remote Sens., 1(4), 818-828 (doi: 10.3390/rs1040818)

Conway H, Smith B, Vaswani P, Matsuoka K, Rignot E and Claus P (2009) A low-frequency ice-penetrating radar system adapted for use from an airplane: test results from Bering and Malaspina Glaciers, Alaska, USA. Ann. Glaciol., 50(51), 93-97 (doi: 10.3189/172756409789097487)

Dowdeswell JA, Benham TJ, Gorman MR, Burgess D and Sharp M (2004) Form and flow of the Devon Island ice cap, Canadian Arctic. J. Geophys. Res., 109(F2), F02002 (doi: 10.1029/ 2003JF000095)

Flanagan C and Laituri M (2004) Local cultural knowledge and water resource management: the Wind River Indian Reservation. Environ. Manage., 33(2), 262-270 (doi: 10.1007/s00267-0032894-9)

Fountain AG, Krimmel RM and Trabant DC (1997) A strategy for monitoring glaciers. USGS Circ. 1132.

Gardner AS and 15 others (2013) A reconciled estimate of glacier contributions to sea level rise: 2003 to 2009. Science, 340(6134), 852-857 (doi: 10.1126/science.1234532)
Gogineni S and 9 others (2001) Coherent radar ice thickness measurements over the Greenland ice sheet. J. Geophys. Res., 106(D24), 33 761-33 772 (doi: 10.1029/2001JD900183)

Hall DK, Foster JL, DiGirolamo NE and Riggs GA (2012) Snow cover, snowmelt timing and stream power in the Wind River Range, Wyoming. Geomorphology, 137(1), 87-93 (doi: 10.1016/j.geomorph.2010.11.011)

Hall MHP and Fagre DB (2003) Modeled climate-induced glacier change in Glacier National Park, 1850-2100. BioScience, 53(2), 131-140 (doi: 10.1641/0006-3568(2003)053[0131:MCIGCI]2. $0 . \mathrm{CO} ; 2)$

Hayden FV (1878) Discovery of recent glaciers in Wyoming. Am. Natur., 12(12), 830-831

Kaser G, Grosshauser M and Marzeion B (2010) Contribution potential of glaciers to water availability in different climate regimes. Proc. Natl Acad. Sci. USA (PNAS), 107(47), 20 223-20 227 (doi: 10.1073/pnas.1008162107)

Kitanidis PK (1997) Introduction to geostatistics: applications in hydrogeology. Cambridge University Press, Cambridge

Kuhn M (1995) The mass balance of very small glaciers. Z. Gletscherkd. Glazialgeol., 31(1-2), 171-179

Lemke P and 10 others (2007) Observations: changes in snow, ice and frozen ground. In Solomon S and 7 others eds, Climate change 2007: the physical science basis. Contribution of Working Group I to the Fourth Assessment Report of the Intergovernmental Panel on Climate Change. Cambridge University Press, Cambridge, 339-383

Lundquist JD, Stewart IT, Dettinger MD and Cayan DR (2009) Variability and trends in spring runoff in the western United States. In Wagner FH ed. Climate warming in western North America: evidence and environmental effects. University of Utah Press, Salt Lake City, UT, 63-76

Mark BG and Seltzer GO (2003) Tropical glacier meltwater contribution to stream discharge: a case study in the Cordillera Blanca, Peru. J. Glaciol., 49(165), 271-282 (doi: 10.3189/ 172756503781830746)

Marston RA, Pochop LO, Kerr GL, Varuska ML and Veryzer DI (1991) Recent glacier changes in the Wind River Range, Wyoming. Phys. Geogr., 12(2), 115-123 (doi: 10.1080/ 02723646.1991.10642421)

Matsuoka K, Maeno H, Uratsuka S, Fujita S, Furukawa T and Watanabe O (2002) A ground-based, multi-frequency icepenetrating radar system. Ann. Glaciol., 34, 171-176 (doi: 10.3189/172756402781817400)

Meier MF (1951) Glaciers of the Gannett Peak-Fremont Peak area, Wyoming. (MS thesis, University of lowa)

Meier MF (1969) Glaciers and water supply. J. Am. Water Works Assoc., 61(1), 8-12

Mingo L and Flowers GE (2010) An integrated lightweight icepenetrating radar system. J. Glaciol., 56(198), 709-714 (doi: 10.3189/002214310793146179)

Moore RD and 7 others (2009) Glacier change in western North America: influences on hydrology, geomorphic hazards and water quality. Hydrol. Process., 23(1), 42-61 (doi: 10.1002/ hyp.7162)

Naftz DL and Smith ME (1993) Ice thickness, ablation, and other glaciological measurements on Upper Fremont Glacier, Wyoming. Phys. Geogr., 14(4), 404-414 (doi: 10.1080/ 02723646.1993.10642488)

Naftz DL and 6 others (2002) Ice core evidence of rapid air temperature increases since 1960 in alpine areas of the Wind River Range, Wyoming, United States. J. Geophys. Res., 107(D13), 4171 (doi: 10.1029/2001JD000621)

Narod BB and Clarke GKC (1994) Miniature high-power impulse transmitter for radio-echo sounding. J. Glaciol., 40(134), 190-194

Nesje A, Bakke J, Dahl SO, Lie Ø and Matthews JA (2008) Norwegian mountain glaciers in the past, present and future. Global Planet. Change, 60(1-2), 10-27 (doi: 10.1016/j.gloplacha.2006.08.004)

Nolan M, Motyka RJ, Echelmeyer K and Trabant DC (1995) Icethickness measurements of Taku Glacier, Alaska, U.S.A., and 
their relevance to its recent behavior. J. Glaciol., 41(139), $541-553$

Nuth C and Kääb A (2011) Co-registration and bias corrections of satellite elevation data sets for quantifying glacier thickness change. Cryosphere, 5(1), 271-290 (doi: 10.5194/tc-5-271-2011)

Østrem G (1966) Mass balance studies on glaciers in Western Canada. Geogr. Bull., 8(1), 81-107

Pelto MS (2006) The current disequilibrium of North Cascade glaciers. Hydrol. Process., 20(4), 769-779 (doi: 10.1002/ hyp.6132)

Pochop LO, Marston R, Kerr G and Varuska M (1989) Long-term trends in glacier and snowmelt runoff, Wind River Range, Wyoming. Wyoming Water Research Center, University of Wyoming, Laramie, WY

Stewart IT, Cayan DR and Dettinger MD (2005) Changes toward earlier streamflow timing across western North America. J. Climate, 18(8), 1136-1155 (doi: 10.1175/JCLI3321.1)

Taylor JR (1982) An introduction to error analysis: the study of uncertainties in physical measurements, 2nd edn. University Science Books, Sausalito, CA

Thompson D, Tootle G, Kerr G, Sivanpillai R and Pochop L (2011) Glacier variability in the Wind River Range, Wyoming. J. Hydrol. Eng., ASCE, 16(10), 798-805 (doi: 10.1061/(ASCE)HE. 1943-5584.0000384
VanLooy JA, Forster RR, Barta D and Turrin J (2013) Spatially variable surface elevation changes and estimated melt water contribution of Continental Glacier in the Wind River Range, Wyoming, USA: 1966-2011. Geocarto Int., 28(2), 98-113 (doi: 10.1080/10106049.2012.665500)

Vuille $M$ and 6 others (2008) Climate change and tropical Andean glaciers: past, present and future. Earth-Sci. Rev., 89(3-4), 79-96 (doi: 10.1016/j.earscirev.2008.04.002)

Wentworth CK and Delo DM (1931) Dinwoody Glaciers, Wind River Mountains, Wyoming: with a brief summary of existing glaciers in the United States. Geol. Soc. Am. Bull., 42(3), 605-620

Xu J and 6 others (2009) The melting Himalayas: cascading effects of climate change on water, biodiversity, and livelihoods. Conserv. Biol., 23(3), 520-530 (doi: 10.1111/j.1523-1739.2009. 01237.x)

Yao TD, Wang YQ, Liu SY, Pu JC, Shen YP and Lu AX (2004) Recent glacial retreat in High Asia in China and its impact on water resource in Northwest China. Sci. China D, 47(12), 1065-1075 (doi: 10.1360/03yd0256)

Zahniser H (1964) The Wilderness Act. An Act to establish a National Wilderness Preservation System for the permanent good of the whole people, and for other purposes. US Public Law 88-577 (16 U.S.C. 1131-1136)

MS received 13 August 2013 and accepted in revised form 13 February 2014 